\title{
Beevor's sign in facioscapulohumeral muscular dystrophy
}

\author{
Chandramohan Sharma, Mihir Acharya, Banshi Lal Kumawat, Kunal Nath
}

Department of Neurology, Sawai Mansingh Medical College and Hospital, Jaipur, Rajasthan, India

\section{Correspondence to} Professor Chandramohan Sharma,

cmsharma65@hotmail.com

Accepted 22 March 2014
CrossMark

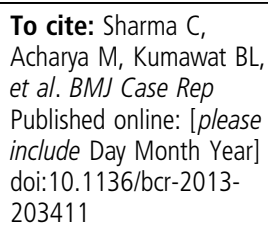

\section{DESCRIPTION}

The Beevor's sign is one of the classic neurological learning signs taught to medical students. It is elicited by asking a supine patient to attempt to get up by raising the head and keeping the arms crossed over the chest, while a marker (a clinical hammer) is kept at the level of the umbilicus to detect the movement of the umbilicus. A positive Beevor's sign is the upward movement of the umbilicus due to cephalad pull of upper abdominal muscles when a patient attempts to raise the head from the supine position. It signifies lower abdominal muscle weakness and has been traditionally described in dorsal myelopathy at D-10 spinal cord level.

Facioscapulohumeral muscular dystrophy (FSHMD) is the third most common muscular dystrophy (after Duchenne and myotonic dystrophy) with an estimated prevalence of 1:20 000. There is usually a distinctive descending evolution of weakness and wasting involving the facial, scapular, humeral, truncal and finally anterolateral leg and pelvic girdle muscles in majority of affected individuals. Classically, the distribution of weakness is symmetrical, as noted in asymmetric scapular winging in our patient (figure 1). Also typical is the 'Popeye' arms due to atrophy of biceps-triceps and selective preservation of deltoid and forearm muscles.

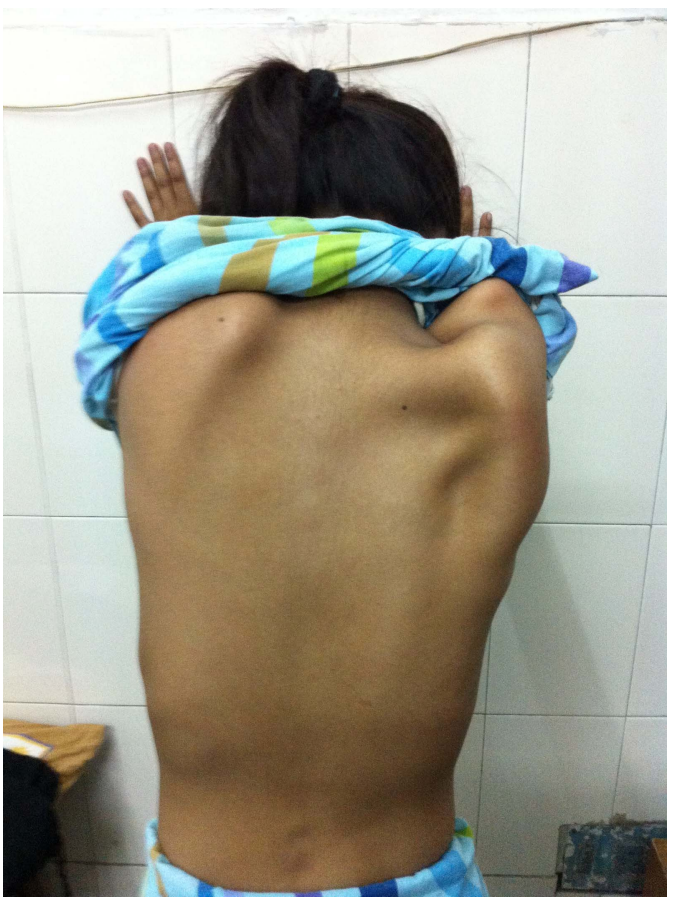

Figure 1 Asymmetric winging of the scapula.
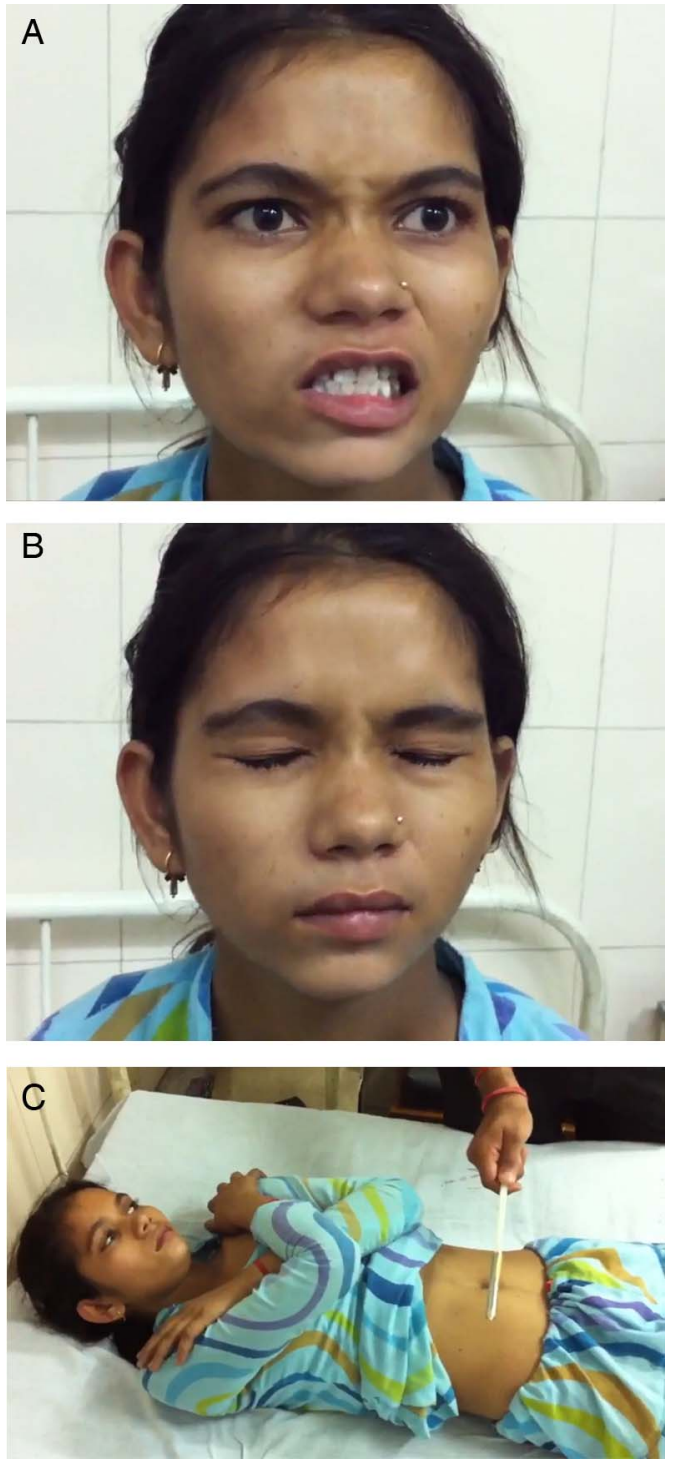

Video 1 In sequential order: (A) Asymmetry of nasolabial folds on being asked to show the teeth (B) incomplete eyelash burrowing on attempted forceful eye closure signifying orbicularis oculi weakness (C) Positive Beevor's sign

A positive Beevor's sign has also been described in FSHMD due to preferential lower abdominal muscle weakness, with an almost 90\% sensitivity and specificity. ${ }^{1-3}$ In FSHMD, it signifies the differential muscle involvement, so characteristic of all the muscular dystrophies. Here, we demonstrate the positive Beevor's sign in a 16-year-old girl with FSHMD (video 1). This clinical sign may be particularly helpful in identifying FSHMD cases presenting with scapulohumeral weakness, but without facial muscle weakness. 


\section{Learning points}

- A positive Beevor's sign is the cephalad movement of the umbilicus when a supine patient attempts to raise the head to get up.

- Two important causes of a positive Beevor's sign are (1) dorsal spinal cord pathology at D-10 spinal level and (2) facioscapulohumeral muscular dystrophy

(FSHMD).

- In FSHMD, a positive Beevor's sign is helpful in clinically identifying cases presenting with scapulohumeral weakness without facial muscle weakness.
Contributors CS, MA, BLK and KN contributed to the planning, conduct and reporting of the work described in the article. All authors read and approved the final manuscript. CS is the guarantor.

Competing interests None.

Patient consent Obtained.

Provenance and peer review Not commissioned; externally peer reviewed.

\section{REFERENCES}

1 Eger K, Jordan B, Habermann S, et al. Beevor's sign in facioscapulohumeral muscular dystrophy: an old sign with new implications. J Neurol 2010;257:436-8.

2 Shahrizaila N, Wills AJ. Significance of Beevor's sign in facioscapulohumeral dystrophy and other neuromuscular diseases. J Neurol Neurosurg Psychiatry 2005;76:869-70.

3 Awerbuch GI, Nigro MA, Wishnow R. Beevor's sign and facioscapulohumeral dystrophy. Arch Neurol 1990;47:1208-9.

Copyright 2014 BMJ Publishing Group. All rights reserved. For permission to reuse any of this content visit http://group.bmj.com/group/rights-licensing/permissions.

BMJ Case Report Fellows may re-use this article for personal use and teaching without any further permission.

Become a Fellow of BMJ Case Reports today and you can:

- Submit as many cases as you like

- Enjoy fast sympathetic peer review and rapid publication of accepted articles

- Access all the published articles

- Re-use any of the published material for personal use and teaching without further permission

For information on Institutional Fellowships contact consortiasales@bmjgroup.com

Visit casereports.bmj.com for more articles like this and to become a Fellow 